\title{
Identification of the spermatogenic stages in living seminiferous tubules of man
}

\author{
V. Nikkanen, K.-O. Söderström* and M. Parvinen* \\ Department of Obstetrics and Gynecology, Turku University Central Hospital, \\ SF-20520 Turku 52, and \\ *Institute of Biomedicine, Department of Anatomy, University of Turku, \\ SF-20520 Turku 52, Finland
}

\begin{abstract}
Summary. Parts of human seminiferous tubules containing late spermatids with condensed nuclei (Stage II) absorbed more transmitted light than did parts at other stages. Spermatogenic stages I, III, IV and VI were identifiable by phase-contrast microscopy.
\end{abstract}

\section{Introduction}

In the rat, the cells of the seminiferous epithelium are arranged in associations with a constant cell composition (Leblond \& Clermont, 1952) which form a succession called the seminiferous epithelial wave (Perey, Clermont \& Leblond, 1961). When isolated unstained preparations of seminiferous tubules are observed under a stereomicroscope, the different cell associations absorb light in differing amounts with the darker areas corresponding to late spermatids which have condensed nuclei (Parvinen \& Vanha-Perttula, 1972). This transillumination technique has been used in the rat for isolation of fragments of seminiferous tubule having a known cell association, and these have been studied further, either morphologically or biochemically (Söderström \& Parvinen, 1976a, b, c, d; Söderström, 1976; Parvinen \& Söderström, 1976). The accuracy of the transillumination technique has been improved by using phase-contrast microscopy which gives accurate morphological information of living spermatogenic cells (Fawcett \& Ito, 1958).

The spermatogenic cells of man also form cell associations with a constant cell composition and six different cell associations, called spermatogenic stages, have been described (Clermont, 1963). The present study was undertaken to determine (1) whether the different stages of the seminiferous epithelium of man absorb light differentially, and whether the different cell associations can be identified with (2) the transillumination method and (3) by phase-contrast microscopy.

\section{Materials and Methods}

The material was obtained from two patients with varicocoeles and slight astheno-teratozoospermia. The testicular biopsy was associated with a reparative operation of the varicocoele. The sample was placed in ice-cold Krebs-Ringer solution (Paul, 1959) and examined under a stereomicroscope within $1 \mathrm{~h}$ after the biopsy. The seminiferous tubules were gently dissected free from the interstitial tissue in a Petri dish containing the Krebs-Ringer solution, photographed in transmitted light and fixed in Bouin's fluid. The sample was then embedded in paraffin wax, sectioned at $5 \mu \mathrm{m}$ and stained with the PAS-haematoxylin technique. For control purposes, a part of each biopsy sample was fixed immediately in Bouin's fluid without separating the seminiferous tubules from the interstitial tissue and processed conventionally for histological examination.

After transillumination other pieces of tubule were transferred to a glass slide and squashed beneath a coverslip to produce a monolayer of cells. The edges of the coverslip were sealed with paraffin oil and the specimen was viewed by phase-contrast microscopy. Photomicrographs were taken with an Union Mic-3Bi inverted microscope by using flashlight. 


\section{Results and Discussion}

Histological examination of the biopsy samples showed that all the testicular components were normal.

In contrast to most mammalian species (Leblond \& Clermont, 1952; Perey et al., 1961; Courot, Hocherau-de Reviers \& Ortavant, 1970), the appearance of the human seminiferous epithelium in histological sections first suggests a random arrangement of the cell types. The existence of a cycle of the seminiferous epithelium in man is, however, now established although the six defined cell associations (Clermont, 1963) are arranged in a mosaic-like fashion in areas of irregular shape. Three or more stages of the cycle may therefore be seen in a single cross-section of a tubule. This arrangement of the seminiferous epithelium can be seen by transillumination of the freshly isolated unstained seminiferous tubules. In the rat, the light absorption of the seminiferous tubules is regular and the existence of the seminiferous epithelial wave is easily recognized. Only at a magnification of $\times 40$ or more could the differences in the absorption pattern of the transmitted light be detected in human seminiferous tubules. When compared with the histological sections, the darker areas were associated with stage II late spermatids with condensed nuclei (PI. 1, Figs 1 and 2). The absorption differences caused by the maturing spermatids along the tubules show that it would be possible to use the transillumination method in man for the isolation of different cell types, in the same way as for rat (Söderström \& Parvinen, 1976a; Söderström, 1976). However, the transillumination technique is morelimited in man because only stage II can be recognized in this way.

Examination of small segments with different transillumination appearance by phase-contrast microscopy gave generally better cellular detail (Pl. 2, Figs 3-7) than after conventional histology, probably because of the cell flattening involved. It was possible to identify different cell types that are known to be present in only one stage and in this way to identify accurately the different spermatogenic stages. Although the mosaic-like arrangement of the spermatogenic cells in the seminiferous tubules of man puts certain restrictions on these methods, it still seems that they could be used as a basis for more detailed morphological, and perhaps biochemical, studies of the test is in normal men and those with spermatogenic disorders.

The action of hormones on the different spermatogenic cell types, particularly in man, is little understood (Steinberger, 1971). The present technique, providing short segments of seminiferous tubules containing accurately identified cells, suggests new possibilities for studies of synthetic activities.

We thank Mrs Leena Simola and Miss Pirjo Vuori for their excellent technical assistance. This work was financially supported by the National Research Council for Medical Sciences (Academy of Finland) and the Finnish Medical Foundation.

\section{References}

Crermont, Y. (1963) The cycle of the seminiferous epithelium in man. Am.J. Anat. 112, 35-52.

Courot, M., Hochereau-de Reviers, M.-T. \& Ortavant, R. (1970) Spermatogenesis. In The Testis, Vol. I. pp. 339-432. Eds A. D. Johnson, W. R. Gomes \& N. L. VanDemark. Academic Press, New York.

FAwCET, D.W. \& ITo, S. (1958) Observations on the cytoplasmic membranes of testicular cells, examined by phase contrast and electron microscopy. $J$. biophys. biochem. Cytol. 4, 135-141.

Leblond, C.P. \& Clermont, Y. (1952) Definition of the stages of the cycle of the seminiferous epithelium in the rat. Ann. N. Y. Acad. Sci. 55, 548--573.

Parvinen, M. \& Söderström, K.-O. (1976) Chromo- some rotation and formation of synapsis. Nature, Lond. 260, 534-535.

Parvinen, M. \& Vanha-Perttula, 1. (1972) Identification and enzyme quantitation of the stages of the seminiferous epithelial wave in the rat. Anat. Rec. 174, 435-450.

Paul, J. (1959) Cell and Tissue Culture. Livingstone, Edinburgh.

Perey, B., Clermont, Y. \& Leblond, C.P. (1961) The wave of the seminiferous epithelium in the rat. $A m . J$. Anat. 108, 47-77.

STEINBERGER, E. (1971) Hormonal control of mammalian spermatogenesis. Physiol. Rev. 51, 1-22.

Söderström, K.-O. (1976) Characterization of RNA 


\section{PLATE 1}

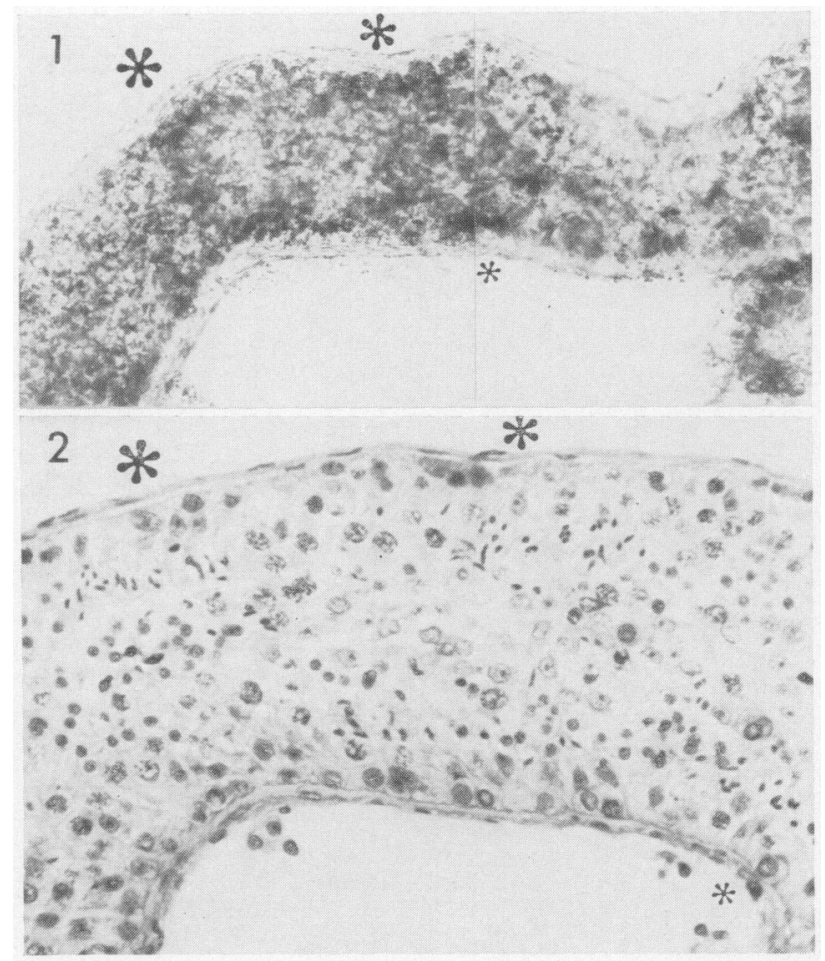

Figs 1 and 2. Transillumination of a freshly isolated unstained normal seminiferous tubule from a 28-yearold man (Fig. 1) and a histological section of the same specimen (Fig. 2). The variation in the light absorption is caused by the different cell associations. Corresponding areas are indicated by asterisks of similar size. The areas are associated with late spermatids with condensed nuclei of stage II. Fig. 1, ×115: Fig. $2, \times 270$. 
PLATE 2
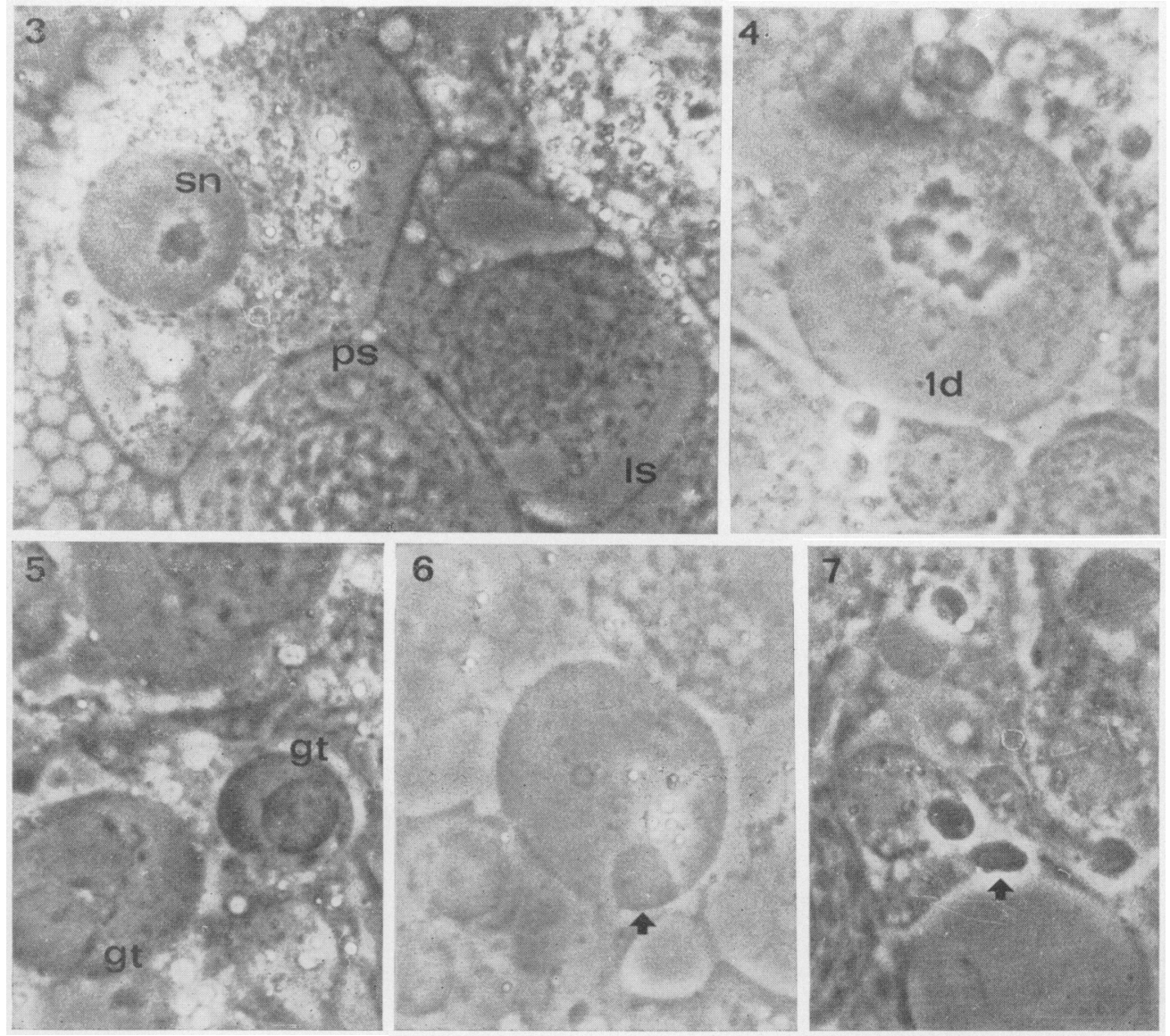

Phase-contrast micrographs of living, flattened, human spermatogenic cells.

Fig. 3. Stage V. The Sertoli cells are characterized by numerous bright lipid droplets and in the nucleus (sn), a prominent dark lobulated nuclcolus can be seen. The leptotene spermatocyte (ls) has thread-like chromosomes, while in the pachytene spermatocyte (ps) the chromosomes are clearly larger. $\times 940$.

Fig. 4. Stage VI. A dividing primary spermatocyte in the first meiotic metaphase (1d). $\times 940$.

Fig. 5. Young round-nucleated spermatids of stage $I(\mathrm{gl})$. The acrosome is a small pale vesicle on the nuclear surface. $\times 940$.

Fig. 6. An acrosome-phase spermatid of stage IV. The nucleus is located peripherally (arrow). $\times 940$.

Fig. 7. Stage I. Spermatids with condensed nuclei (arrow). $\times 940$. 
synthesis in the mid pachytene spermatocytes of the rat. Expl Cell Res. 102, 237-245.

Söderström, K.-O. \& PARvineN, M. (1976a) RNA synthesis in different stages of rat seminiferous epithelial cycle. Molec. cell. Endocr. 5, 181-199.

Söderström, K.-O. \& Parvinen, M. (1976b) DNA synthesis during male meiotic prophase in the rat. Hereditas 82, 25-28.
SöderströM, K.-O. \& PARVINEN, M. (1976c) Transport of material between the nucleus, the chromatoid body and the Golgi complex in the early spermatids of the rat. Cell Tiss. Res. $168,335-342$.

Söderström, K.-O. \& PaRvinen, M. (1976d) Incorporation of ${ }^{3} \mathrm{H}$-uridine by the chromatoid body during rat spermatogenesis. J. Cell Biol. 70, 239-246.

Received 26 September 1977 